\title{
Enhancing health and independent living for veterans with disabilities by leveraging community-based resources
}

This article was published in the following Dove Press journal:

Journal of Multidisciplinary Healthcare

20 January 2017

Number of times this article has been viewed

\author{
Jennifer Hale-Gallardo' \\ Huanguang Jia' \\ Tony Delisle 2 \\ Charles E Levy ${ }^{1,3-5}$ \\ Valentina Osorio' \\ Jennifer A Smith' \\ Elizabeth M Hannold ${ }^{\prime, \dagger}$ \\ 'Center of Innovation on Disability \\ and Rehabilitation Research, North \\ Florida/South Georgia Veterans Health \\ System, ${ }^{2}$ Center for Independent Living \\ of North Central Florida, ${ }^{3}$ Physical \\ Medicine and Rehabilitation Service, \\ North Florida/South Georgia Veterans \\ Health Service, ${ }^{4}$ The Department \\ of Occupational Therapy, College of \\ Public Health and Health Professions, \\ ${ }^{5}$ The Center for the Arts in Medicine, \\ College of the Arts, University of \\ Florida, Gainesville, FL, USA
}

tElizabeth M Hannold passed away on September 28, 2015.

Correspondence: Jennifer Hale-Gallardo Center of Innovation on Disability and Rehabilitation Research, North Florida/ South Georgia Veterans Health System, 160I SW Archer Road I5I-B, Gainesville, FL 32608, USA

Tel + I 352376 I6I I ext 4947

Fax +I $35238 \mid 5750$

Email Jennifer.Hale-Gallardo@va.gov

\begin{abstract}
The number of US veterans with disabilities has increased in recent years as service members have returned home with extensive injuries and veterans from previous wars acquire functional limitations as a consequence of aging with chronic diseases. Veterans with severe disabilities need assistance and support to maintain independence at home and to avoid institutionalization. The US Department of Veterans Affairs (VA) strives to network with community organizations to achieve the best possible outcomes for veterans. Key community resources in the US for individuals with disabilities are Centers for Independent Living (CILs) that provide a wide range of services, promoting independent living and well-being for people across disabilities. The widespread availability and services of CILs nationwide suggest their potential as a community-based resource for veterans, particularly for those with limited access to VA care. In this article, we discuss long-term needs of veterans with disabilities, efforts to address veterans' rehabilitation needs at the VA and opportunities for leveraging the strengths of community-based organizations for veterans. More research is warranted to investigate CIL services and potential for CIL-VA partnerships.
\end{abstract}

Keywords: rehabilitation, community engagement, community reintegration, functional limitations

\section{Introduction}

Disability is a major issue for US veterans and, thus, a significant concern of the Veterans Health Administration (VHA) of the US Department of Veterans Affairs (VA). In 2015, >4.5 million veterans received compensation for service-connected disabilities, including 42.5\% Gulf War Era Veterans (1990-till date). ${ }^{1}$ This number excludes veterans living with functional impairment not related to military services. Moreover, the numbers of veterans with disabilities are expected to increase as veterans from previous conflicts age and acquire the physiological, cognitive and psychological declines of later life. ${ }^{2-5}$ As veterans' needs for long-term services and care increase so does the need for cost-effective approaches to provide support for veterans living in the community. One potential partner in the battle to promote independence despite disability is the national network of Centers for Independent Living (CILs). In this article, we discuss some of the long-term needs of veterans with disabilities, particularly those with physical and mental disabilities, and efforts to address veterans' rehabilitation needs at the VA, as well as opportunities for leveraging the strengths of CILs to serve veterans.

The Operation Enduring Freedom (OEF), Operation Iraqi Freedom (OIF) and Operation New Dawn (OND) conflicts have been called the wars of disabilities due to the higher survival rate of troops exposed to explosive munitions and blasts resulting 
in a dramatic increase in amputations, traumatic brain injury (TBI), facial trauma, spinal cord injuries and vision and hearing impairments. ${ }^{6-9}$ Protective technologies coupled with medical innovations have enabled troops to increasingly survive warfare with polytraumatic injuries - characterized as injuries to two or more physical regions or organ systems with at least one injury that is life threatening. Many of these survivors will carry the burden of a constellation of physical, cognitive and psychological impairments. ${ }^{89}$ As of October 2016, 59,360 OEF-OIF-OND military personnel have been wounded in action. ${ }^{10}$ Still others have been diagnosed with combat-related injuries after returning from deployment, such as posttraumatic stress disorder (PTSD), ${ }^{11}$ or have acquired new injuries. ${ }^{12}$

Newly acquired impairments bring with them a wide range of psychological, cognitive and behavioral challenges, as well as concerns about future quality of life. ${ }^{13}$ In addition to physical injury, many veterans suffer from significant mental health problems. ${ }^{14}$ For OIF-OEF-OND veterans, their signature injuries of TBI, PTSD and sleep disorders often overlap with other comorbidities such as depression and depressive mood disorders, substance abuse, and other related mental disorders. ${ }^{15}$ Moreover, the long-term effects of high combat stress are substantial as veterans integrate traumatic war experiences and adjust to disabling conditions. ${ }^{16}$

Veterans also face factors that may lead to an increased risk of developing disabilities over time as they age. ${ }^{17}$ Veterans tend to have more comorbidities than age-matched nonveterans. ${ }^{18}$ Moreover, elderly Veteran enrollees can face higher disease burden and lower health-related quality of life outcomes than nonveterans. ${ }^{5}$ Consequently, researchers have suggested that military service is a hidden variable in aging outcomes among veterans..$^{17,19}$

Aging can also complicate preexisting disabilities and provoke secondary conditions..$^{20,21}$ For instance, individuals with spinal cord injury (SCI) are at a higher risk of stroke than the general population, and those with amputations or limb loss are increasingly prone to cardiovascular disease, obesity, joint pain, arthritis, back pain and mental health problems. ${ }^{22,23}$ One study found that four decades after the Vietnam War, $\sim 70 \%$ of these veterans had developed at least one combatrelated disability and many had developed multiple eye and ear, mental health and musculoskeletal disorders. ${ }^{24}$

Due to the medical, vocational and social integration needs of veterans with disabilities, an interdisciplinary coordination of care, services and support is crucial. ${ }^{25}$ Many veterans with severe disabilities will require long-term follow-up and support after rehabilitation. ${ }^{26}$ Many will also need timely interventions and preventive well-being programs (eg, weight control, stress reduction and exercise) in order to avoid secondary and tertiary conditions since individuals with disabilities are at a higher risk of medical complications. ${ }^{27,28}$ It is also vital to address the existential and social needs of veterans $^{29}$ and provide additional resources and support to families and caregivers. ${ }^{30}$

\section{Demand is greater than capacity}

The VA runs a comprehensive health care delivery system to provide health care for Veteran enrollees. ${ }^{31-33}$ For veterans with disabilities, health care and support are delivered through physical medicine and rehabilitation, telehealth, Vocational Rehabilitation and Employment (VR\&E), community-based medical care, mental health counseling, residential centers, assisted living facilities, nursing homes and caregiver programs. The VHA provides institutional long-term care needed by veterans at 133 Community Living Centers and through contracts with thousands of community nursing homes and other long-term care facilities, as needed. ${ }^{34}$ VHA also runs $>300$ Vet Centers providing noninstitutional social and psychological services to veterans and families, as well as support of informal caregivers who assist veterans with disabilities at home. ${ }^{35}$

The great demand for service and support by veterans with disabilities can be gleaned from VA statistics on veterans' clinical encounters. In 2014, VA's Physical Medicine and Rehabilitation physicians and therapists treated $>850,000$ unique patients with $>4.6$ million total encounters. ${ }^{36}$ In 2015 , the VA provided specialized mental health treatment to 1.6 million veterans, ${ }^{37}$ occupational therapy services to 358,853 patients $^{38}$ and supported employment services to $>80,000$ veterans. ${ }^{35}$ Moreover, the VA admits $\sim 6,000$ veterans for acute ischemic stroke each year ${ }^{39}$ and treats $>27,000$ veterans with SCI annually. ${ }^{40}$

Although the VA offers many supportive programs for veterans with disabilities, not all veterans are eligible and some Veterans have limited access to VA programs. For example, each year, only half of the 65,000 Veteran applicants are admitted to the VR\&E program to receive assistance with employment and career development counseling. ${ }^{41}$ In addition, while the VR\&E offers an Independent Living Program to enhance activities of daily living for service-connected veterans who are unable to work, this program is limited to 2 years and has an enrollment capacity of 2,700 per year. ${ }^{42,43}$

The VA Under Secretary of Health, Dr. David Shulkin, recently reported that while the VA outperforms private industry, demand for services exceeds infrastructure capacity. ${ }^{44}$ In response, he proposed building a VHA high- 
performance network to meet the needs of veterans by partnering with non-VA resources for acute care and subacute care. This strategy, however, should also include networking with community-based, non-VA resources to address the need for long-term services and nonmedical care by veterans with disabilities.

The needs of veterans with disabilities are expected to overwhelm the existing resources of the VHA. ${ }^{24,30,45,46}$ Veterans with disabilities in particular tend to have worse health outcomes and require significantly more care. ${ }^{47,48}$ If similar patterns follow from previous conflicts, additional resources will be necessary to prevent and treat long-term health conditions for this population. ${ }^{45,49}$ Furthermore, veterans aged 65 years or older currently number 12.4 million, ${ }^{50}$ and many will develop chronic diseases associated with aging. Similarly, in the next two decades, veterans from the wars in Iraq and Afghanistan will begin to face age-related health issues similar to current Vietnam veterans. ${ }^{24,45}$

\section{Centers for Independent Living (CILs)}

CILs are community-based organizations offering services and support to people with disabilities across the US. ${ }^{51}$ Congressionally mandated under the US Federal Rehabilitation Act amendment of 1978, CILs are consumer-controlled, cross-disability, nonresidential private nonprofit agencies that, 1) are designed and operated within a local community by individuals with disabilities, and 2) provide independent living (IL) services. ${ }^{52,53}$ Formerly, under the US Department of Education, today CILs report to the Department of Health and Human Services' Administration for Community Living (ACL), which has the mission of maximizing the independence, well-being and health of individuals with disabilities across their lifespan and for their families and caregivers. ${ }^{54}$

IL at its most basic is about personal control over one's life and ability to participate fully in society, such as working, having a home, raising a family and being a part of a community. ${ }^{55,56}$ IL emerged as a movement in the 1960 's -1970 's to counter a societal tendency to relegate persons with disabilities to a dependent sick role status and grant ultimate decision-making authority over their lives to medical professionals, family members and others. ${ }^{57}$ Today the IL movement continues to call attention to the environmental and social barriers that hold people back from full participation in their communities, including inaccessible environments, unaffordable or inaccessible housing, lack of transportation and opportunities for employment. ${ }^{58}$

There are $>650$ CILs throughout the US and each is mandated to provide at least the following five core services: peer support, information and referral, individual and systems advocacy, IL skills training and transitions support. ${ }^{59}$ CILs are a clearinghouse for information on a wide range of topics, including housing, transportation, disability law, job readiness training, and recreation and social opportunities. Peer counselors at CILs offer a firsthand knowledge of effective coping skills and provide role models for personal, social and economic achievements. IL skill programs at CILs foster skill development to support personal growth, decision making, problem solving, self-advocacy and autonomy. CILs provide advocacy to assist individuals and families in identifying barriers at the individual and systemic levels and prevent institutionalization by assisting with transitions into the community.

While CILs have been of interest to researchers in rehabilitation, medicine, social work and education, research on CILs has been sparse. ${ }^{60,61} \mathrm{~A}$ few studies have reported on the ethical dilemmas encountered by IL service providers ${ }^{62}$ and the impact of cultural brokering training to enhance the cultural competence of CIL staff. ${ }^{63}$ More recent studies have focused on understanding how to serve emerging disabilities better $^{64}$ and expanding online services offered by CILs in order to help individuals from their homes. ${ }^{65}$ Studies have also addressed psychosocial and environmental factors impacting persons with disabilities and bridging gaps from institutions to community life. ${ }^{66-68}$

Several early evaluations exist of CILs profiling the services and clients, but the majority of these were primarily descriptive ${ }^{69-72} \mathrm{~A}$ comprehensive evaluation of the CILs program in 2003 reported state-by-state comparisons of services from 255 CILs to $>188,000$ people with disabilities. ${ }^{73}$ In this survey, of the 569 consumers with disabilities interviewed, most CIL users were people with nonorthopedic physical disabilities (49\%), visual impairments $(37 \%)$, orthopedic impairments, including amputations (31\%), and mental illness or psychiatric disability (28\%). ${ }^{74}$ Studies have called for further assessment of CIL services and the development of relevant tools or instruments for evaluation. ${ }^{75-78}$ Current mechanisms for monitoring the quality and efficacy of CILs programming are through an IL plan created for each CIL client and monitored monthly, quarterly and yearly to determine whether goals were met (Delisle, personal communication, October, 2016). Open-ended satisfaction surveys are also conducted to provide insight into the type of care provided, and program utilization is tracked.

Some of the most compelling work on CILs has proposed that they have a role in preventing and managing secondary conditions resulting from an underlying impairment or func- 
tional limitation (ie, pressure sores, urinary tract infections and psychosocial issues). ${ }^{79,80}$ In recent years, the potential relevance of CILs for reducing the incidence and severity of secondary conditions has been explored through the implementation of health promotion programs at CILs. ${ }^{77,81}$ Other studies have also considered the health promotion potential of CILs, such as programs for substance use disorders ${ }^{82}$ and tobacco cessation. ${ }^{83}$

There are several aspects of CILs that make them unique organizations. First of all, CILs are cross-disability, meaning that they serve individuals with any kind of disability or impairment. CILs provide a kind of storefront access to a wide variety of services and resources that help contribute to IL. ${ }^{58}$

Furthermore, while the rehabilitation field has long stressed outcomes, such as self-care, mobility and employment, the IL movement has expanded these outcomes to include person-centered outcomes such as efficacy in determining one's own living arrangements, directing one's own disability service provision and participating in outof-home activities. ${ }^{51,84}$ CILs personalization of services and support offered to their consumers is consistent with trends in the medical and rehabilitation fields to emphasize persondirected care and patient-directed outcomes.

Finally, the CIL model of combined service delivery and advocacy at the individual and system levels targets some of the most critical social determinants of health for people with disabilities - those social, economic and environmental conditions that shape health status. CILs have long-addressed social determinants that the World Health Organization acknowledges as key for reducing health inequities, such as promoting access to adequate housing, education, transportation, and employment that encourages positive social relationships in the workplace. ${ }^{85}$

\section{Leveraging CILs to meet the IL needs of veterans with disabilities}

CILs provide many resources that can help facilitate the well-being and fuller integration of individuals with disabilities into their communities. However, communication between CILs and members of the rehabilitation community has been largely unexplored ${ }^{86}$ In a qualitative pilot study on veterans' use of CILs in Florida (2007), Hannold telephoneinterviewed administrators from Florida CILs on their knowledge of and desire to work with veterans (Hannold, unpublished data, 2008). Telephone interviews with 14 of the 16 directors of CILs in Florida (response rate $=87.5 \%$ ) were conducted regarding the services that they were providing to veterans, attitudes toward serving veterans and the knowledge of injuries that disproportionately affect veterans, such as polytrauma and PTSD. Hannold's study revealed that the majority of Centers reported serving veterans, although 10 Centers reported that they did not routinely ask about Veteran status during referral and intake and five Centers were not tracking veterans in their demographic profiles. Findings also suggested the need for a better understanding within CILs and the VA about the services and supports that each organization provides. In addition, Hannold found that some CIL staff desired additional training on polytrauma and PTSD, as well as wanted to improve their understanding of the combat experiences of veterans and related mental health issues. Hannold concluded that an important potential exists for VA and CILs to work together to assist veterans as they returned from overseas deployment into their communities.

A few years after Hannold's pilot study in 2011, a memorandum of understanding (MoU) was signed between the National Council on Independent Living (NCIL), the Association of Programs for Rural Independent Living (APRIL) and VA VR\&E service. The MoU recognized an opportunity for joining efforts to serve veterans with disabilities by helping veterans develop and meet personal goals through problem-solving and self-advocacy skills, community volunteer opportunities, computer literacy training, VR\&E services and advocating for appropriate housing or home modifications. ${ }^{87}$ The MoU was a positive milestone for furthering VA-CIL collaborations; however, its implementation and impact on veterans' health and IL remain unknown.

With a history of providing supports to people with disabilities in the community, CILs may be uniquely positioned to serve as an important component of a "health neighborhood" for veterans with disabilities, especially for those who continue to readjust to life with combat-related physical or mental disabilities ${ }^{88} \mathrm{CILs}$ may also be important for veterans with disabilities who may be reluctant to seek treatment in VA settings or who reside at a distance from the VA. CILs could also have a role to play in the reintegration of veterans into the civilian community since the majority of CILs' work has been with nonveterans but their consumers have also included veterans.

\section{Conclusion}

There are a large number of veterans with physical and mental disabilities. The demand for services and support for promoting IL in their communities as well as preventing secondary conditions is beyond the VA capacity. CILs may be uniquely positioned to meet the needs of the veterans and fill in gaps for 
the VA's long-term care. Non-VA community-based resources such as CILs can be leveraged by developing partnerships or networks between VA and CILs. Despite the history of service to veterans, there is a lack of documentation about CIL-VA collaborations and a lack of knowledge on CILs' capacities to serve veterans. Further research is warranted to, 1) evaluate the quality of services offered by CILs, either qualitatively or through standard questionnaires, and 2) investigate the feasibility of leveraging CILs to meet the nonmedical care needs of veterans.

\section{Disclosure}

The opinions and contents of this article are those of the authors, and they do not represent the views of the VA or the United States Government. The authors report no conflicts of interest in this work.

\section{References}

1. United States Department of Veteran Affairs (VA). National Center for Veterans Analysis and Statistics. Veterans Compensation and Pension by County. 2015. Available from: https://www.va.gov/vetdata/report. asp. Accessed April 8, 2016

2. Wilmoth JM, London AS. Aging veterans: needs and provisions. In: Settersten AR, Angel LJ, editors. Handbook of Sociology of Aging. New York: Springer; 2011:445-461.

3. Taylor MG, Ureña S, Kail BL. Service-related exposures and physical health trajectories among aging veteran men. Gerontologist. 2016; 56(1):92-103.

4. Wiechers IR, Karel MJ, Hoff R, Karlin BE. Growing use of mental and general health care services among older veterans with mental illness. Psychiatr Serv. 2015;66(11):1242-1244.

5. Selim AJ, Berlowitz DR, Fincke G, et al. The health status of elderly veteran enrollees in the veterans health administration. $J$ Am Geriatr Soc. 2004;52(8):1271-1276.

6. Fausti SA, Wilmington DJ, Gallun FJ, Myers PJ, Henry JA. Auditory and vestibular dysfunction associated with blast-related traumatic brain injury. J Rehabil Res Dev. 2009;46(6):797-810.

7. Okie S. Traumatic brain injury in the war zone. $N$ Engl J Med. 2005; 352(20):2043-2047.

8. Pugh MJ, Finley EP, Copeland LA, et al. Complex comorbidity clusters in OEF/OIF veterans: the polytrauma clinical triad and beyond. Med Care. 2014;52(2):172-181.

9. Lew HL. Rehabilitation needs of an increasing population of patients: traumatic brain injury, polytrauma, and blast-related injuries. J Rehabil Res Dev. 2005;42(4):xiii-xvi.

10. United States Department of Defense. Defense Casualty Analysis System: US military casualties - Operation Iraqi Freedom (OIF) Casualty Summary by Casualty Category. 2014. Available from: https://www. dmdc.osd.mil/dcas/pages/report_oif_type.xhtml. Accessed April 8, 2016

11. Tanielian T, Haycox LH, editors. Invisible Wounds: Mental Health and Cognitive Care Needs of America's Returning Veterans. Santa Monica: RAND Corporation; 2008.

12. Carlson KF, Meis LA, Jensen AC, et al. Caregiver reports of subsequent injuries among veterans with traumatic brain injury after discharge from inpatient polytrauma rehabilitation programs. $J$ Head Trauma Rehabil. 2012;27(1):14-25.

13. Beder J, Jones H. When they return: The needs of the wounded. In: Beder J, editor. Advances in Social Wk Practice with the Military. New York: Routledge; 2012:92-105.

14. Seal KH, Bertenthal D, Miner CR, Sen S, Marmar C. Bringing the war back home: mental health disorders among 103,788 US veterans returning from Iraq and Afghanistan seen at department of veterans affairs facilities. Arch Intern Med. 2007;167(5):476-482.
15. MacGregor AJ, Shaffer RA, Dougherty AL, et al. Psychological correlates of battle and nonbattle injury among operation Iraqi freedom veterans. Mil Med. 2009;174(3):224-231.

16. Frain MP, Bishop M, Bethel M. A roadmap for rehabilitation counseling to serve military veterans with disabilities. J Rehabil. 2010;76(1):13-21.

17. Spiro A 3rd, Settersten RA Jr. Long-term implications of military service for later-life health and well-being. Res Hum Dev. 2012;9:183-190.

18. Kazis LE, Miller DR, Clark J, et al. Health-related quality of life in patients served by the Department of Veterans Affairs: results from the veterans health study. Arch Intern Med. 1998;158(6):626-632.

19. Settersten RA. When nations call: how wartime military service matters for the life course and aging. Res Aging. 2006;28:12-36.

20. Verbrugge LM, Yang LS. Aging with disability and disability with aging. J Disabil Policy Study. 2002;12:253-267.

21. Rajan KB, Hebert LE, Scherr PA, Mendes de Leon CF, Evans DA. Disability in basic and instrumental activities of daily living is associated with faster rate of decline in cognitive function of older adults. J Gerontol A Biol Sci Med Sci. 2013;68(5):624-630.

22. Foote CE, Kinnon JM, Robbins C, Pessagno R, Portner MD. Long-term health and quality of life experiences of Vietnam veterans with combatrelated limb loss. Qual Life Res. 2015;24(12):2853-2861.

23. Rose HG, Schweitzer P, Charoenkul V, Schwartz E. Cardiovascular disease risk factors in combat veterans after traumatic leg amputations. Arch Phys Med Rehabil. 1987;68(1):20-23.

24. Clarke PM, Gregory R, Salomon JA. Long-term disability associated with war-related experience among vietnam veterans: retrospective cohort study. Med Care. 2015;53(5):401-408.

25. Sayer NA, Carlson KF, Frazier PA. Reintegration challenges in US service members and veterans following combat deployment. Soc Issues Policy Rev. 2014;8:33-73.

26. Lew HL, Otis JD, Tun C, et al. Prevalence of chronic pain, posttraumatic stress disorder, and persistent postconcussive symptoms in oif/oef veterans: polytrauma clinical triad. J Rehabil Res Dev. 2009;46(6):697-702.

27. Kinne S, Patrick DL, Doyle DL. Prevalence of secondary conditions among people with disabilities. Am J Public Health. 2004;94(3):443-445.

28. Drum CE, Krahn G, Culley C, Hammond L. Recognizing and responding to the health disparities of people with disabilities. Californian $J$ Health Promot. 2005;3:29-42.

29. Fritz HA, Lysack C, Luborsky MR, Messinger SD. Long-term community reintegration: concepts, outcomes and dilemmas in the case of a military service member with a spinal cord injury. Disabil Rehabil. 2015;37(16):1501-1507.

30. Link PE, Palinkas LA. Long-term trajectories and service needs for military families. Clin Child Fam Psychol Rev. 2013;16(4):376-393.

31. Howell P, Capehart BP, Hoenig H. Rehabilitation of combat-related injuries in the veterans administration: a web of support. $N C$ Med $J$. 2015;76(5):323-327.

32. Evashwick C. The Continuum of Long-Term Care. Boston: Cengage Learning; 2005.

33. Department of Veterans Affairs: Veterans Health Administration Directive 2005-024: Polytrauma Rehabilitation Centers. Washington, DC, Veterans Health Administration. June 8, 2005.

34. Jia H, Pei Q, Sullivan CT, et al. Poststroke rehabilitation and restorative care utilization: a comparison between VA community living centers and VA-contracted community nursing homes. Med Care. 2016; 54(3):235-242.

35. United States Department of Veterans Affairs. VA Mental Health Care Fact Sheet 2016. Available from: http://www.va.gov/opa/publications/ factsheets/April-2016-Mental-Health-Fact-Sheet.pdf. Accessed October 3, 2016.

36. United States Department of Veterans Affairs. Physical Medicine and Rehabilitation Fact Sheet 2015. Available from: http://www.va.gov/ opa/publications/factsheets/April-2016-Mental-Health-Fact-Sheet.pdf. Accessed October 3, 2016.

37. United States Department of Veterans Affairs. Fact Sheet-Mental Health Care for Service Members, Veterans and Families 2016. Available from: http://www.blogs.va.gov/VAntage/wp-content/uploads/2016/06/160606_ MentalHealthSummaryofEfforts.pdf. Accessed October 3, 2016. 
38. United States Department of Veterans Affairs. Occupational Therapy Fact Sheet. Washington, DC: 2015. Available from: http://www.rehab. va.gov/factsheet/OT-FactSheet.pdf. Accessed July 26, 2016.

39. Stroke QUERI Fact Sheet 2014. Washington, DC. Available from: http://www.queri.research.va.gov/about/factsheets/stroke_factsheet. pdf. Accessed July 26, 2016.

40. United States Department of Veterans Affairs. VA Research on Spinal Cord Injury. 2015. Available from: www.research.va.gov/pubs/docs/ va_factsheets/sci.pdf. Accessed November 3, 2016.

41. United States Government Accountability Office (US. GAO). VA Vocational Rehabilitation and Employment Progam: Improved Oversight of Independent Living Services and Supports Is Needed. 2013. Available from: http://www.gao.gov/assets/660/655087.pdf. Accessed April 8, 2016.

42. Veteran Benefits Administration [webpage on the Internet]. Vocational Rehabilitation and Employment (VR\&E): Independent Living. Available from: http://www.benefits.va.gov/vocrehab/independent_living.asp. Accessed April 8, 2016.

43. Collins B. Veterans' Benefits: The Vocational Rehabilitation and Employment Program. 2012. Available from: https://www.hsdl. org/?view\&did=706744. Accessed April 8, 2016.

44. Shulkin DJ. Beyond the VA crisis - becoming a high-performance network. N Engl J Med. 2016;374:1003-1005.

45. Geiling J, Rosen JM, Edwards RD. Medical costs of war in 2035: longterm care challenges for veterans of Iraq and Afghanistan. Mil Med. 2012;177(11):1235-1244.

46. Bilmes L. Soldiers returning from Iraq and Afghanistan: the long-term costs of providing Veterans medical care and disability benefits. Harvard University, John F. Kennedy School of Government, Faculty Research Working Papers Series, Jan 2007:16-17. Available from: https://www. clark.wa.gov/sites/all/files/public-health/veterans-assistance/ReturningSoldiers.pdf. Accessed July 26, 2016.

47. Wu L, Lewis MW. Disabilities among veterans and their utilization of health care. Health Psychol Behav Med. 2015;3:296-314.

48. Drag L, Renninger C, King R, Hoblyn J. Predictors of inpatient and outpatient healthcare utilization in veterans with traumatic brain injury. J Head Trauma Rehabil. 2013;28(1):39-47.

49. Sorrell JM, Durham S. Meeting the mental health needs of the aging veteran population. J Psychosoc Nurs Ment Health Serv. 2011;49(1):22-25.

50. United States Census Bureau. Statistical Abstract of the United States: 2012. Available from: https://www2.census.gov/library/publications/2011/ compendia/statab/131ed/2012-statab.pdf. Accessed April 8, 2016.

51. DeJong G. Independent living: from social movement to analytic paradigm. Arch Phys Med Rehabil. 1979;60(10):435-446.

52. Usiak DJ, Moffat J, Wehmeyer ML. Independent living management. J Vocat Rehabil. 2004;20:1-3.

53. United States Congress. Rehabilitation, comprehensive services, and developmental disabilities amendments of 1978. Public Law. 1978;95:602.

54. U.S. Department of Health and Human Services Administration for Community Living (ACL). Strategic Plan 2013-2018. Available from: http://www.acl.gov/About_ACL/StrategicPlan/docs/ACL_Strategic_Plan.pdf. Accessed June 1, 2016.

55. Lachat MA. The Independent Living Service Model: Historical Roots, Core Elements, and Current Practice. Hampton: Center for Resource Management; 1988. Available from: http://www.mwcil.org/home/files/ disc_edit_il_philosophy_1final_copy.pdf. Accessed March 3, 2016.

56. Shapiro JP. No Pity: People with Disabilities Forging a New Civil Rights Movement. New York: Three Rivers Press; 1994.

57. Hayes J, Hannold EM. The road to empowerment: a historical perspective on the medicalization of disability. J Health Hum Serv Adm. 2007; 30(3):352-377.

58. White GW, Simpson JL, Gonda C, et al. Moving from independence to interdependence: a conceptual model for better understanding community participation of centers for independent living consumers. $J$ Disabil Policy Stud. 2010;20:233-240.

59. National Council on Independent Living [webpage on the Internet]. About Independent Living. Available from: http://www.ncil.org/about/ aboutil/. Accessed October 3, 2016.
60. Nosek MA, Roth PL, Zhu Y. Independent living programs: the impact of program age, consumer control, and budget on program operation. J Rehabil. 1990;56:28.

61. Woodill G. Independent Living and Participation in Research: A Critical Analysis. 2006. Available from: cepvi.org/admin/directorio/files/ ilservices.pdf. Accessed April 8, 2016.

62. Wong HD, Millard RP. Ethical dilemmas encountered by independent living service providers. $J$ Rehabil. 1992;58:10.

63. Moffat J, Tung J-Y. Evaluating the effectiveness of culture brokering training to enhance cultural competence of independent living center staff. J Vocat Rehabil. 2004;20:59-69.

64. Kim K, Fox MH. Knocking on the door: the integration of emerging disability groups into independent living. J Vocat Rehabil. 2004;20: 91-98.

65. Ritchie H, Blanck P. The promise of the internet for disability: a study of on-line services and web site accessibility at centers for independent living. Behav Sci Law. 2003;21(1):5-26.

66. Wehmeyer ML, Gragoudas S. Centers for independent living and transition-age youth: empowerment and self-determination. $J$ Vocat Rehabil. 2004;20:53-58.

67. Nary DE [webpage on the Internet]. Assessing the health promotion needs of center for independent living consumers with physical disabilities. 2015 APHA Annual Meeting \& Expo (October 31-November 4, 2015). Available from: https://apha.confex.com/apha/143am/webprogram/Paper335924.html. Accessed April 8, 2016.

68. Tomita MR, Usiak DJ, Moffat J. Profile of centers for independent living based on the national CIL management database. J Vocat Rehabil. 2004;20(1):21-34.

69. Stoddard S. Evaluating program methods and results. In: Crewe N, editor. Independent Living for Physically Disabled People. San Francisco: Jossey-Bass; 1983:273-291.

70. Clowers M, Haley D, Unti W, Feiss C. Independent Living Project: Final Report. Seattle, WA: Division of Vocational Rehabilitation and University of Washington; 1979.

71. Budde JF, Petty CR, Nelson C, Couch RW. Evaluating the impact of independent living centers on consumers and the community. J Rehabil. 1986;52:68.

72. Jones ML, Petty C, Bolles C, Mathews RM. Independent living: a survey of program and service needs. Rehabil Couns Bull. 1986;29(4): 278-283.

73. O'Day B, Wilson J, Killeen M, Ficke R. Consumer outcomes of centers for independent living program. J Vocat Rehabil. 2004;20:83-89.

74. CESSI. Evaluation of the Centers for Independent Living Program. 2003. Available from: https://www2.ed.gov/rschstat/eval/rehab/2003il-final-report.pdf. Accessed October 3, 2016.

75. DeJong G, Hughes J. Independent living: methodology for measuring long-term outcomes. Arch Phys Med Rehabil. 1982;63(2):68-73.

76. Georgiades S. A multi-outcome evaluation of an independent living program. Child Adolesc Soc Work J. 2005;22:417-439.

77. Ravesloot CH, Seekins T, Cahill T, Lindgren S, Nary DE, White G. Health promotion for people with disabilities: development and evaluation of the living well with a disability program. Health Educ Res. 2007;22(4):522-531.

78. Budde J, Petty CR, Nelson C. Problems and benefits associated with consumer satisfaction evaluation at independent living centers. J Rehabil. 1989;55:62-68.

79. White GW, Gutierrez RT, Seekins T. Preventing and managing secondary conditions: a proposed role for independent living centers. J Rehabil. 1996;62(3):14-20.

80. Seekins T, Smith N, McCleary T, Clay J, Walsh J. Secondary disability prevention: involving consumers in the development of a public health surveillance instrument. J Disabil Policy Stud. 1990;1:21-36.

81. Ravesloot C, Seekins T, Traci M, et al. Living well with a disability, a self-management program. MMWR Suppl. 2016;65(1):61-67.

82. Hepner R, Kirshbaum H, Landes D. Counseling substance abusers with additional disabilities: the center for independent living. Alcohol Res Health. 1980;5:11. 
83. Moorhouse MD, Pomeranz JL, Barnett TE, et al. Tobacco cessation intervention for people with disabilities: survey of center for independent living directors. Rehabil Couns Bull. 2011;54:118-121.

84. Shreve ML, Spiller PA, Griffin EL, Waldron N, Stolzman L. Consumer Control in Independent Living. The Center for Resource Management, Inc and The National Council on Independent Living. 1998. Available from: http://www.mwcil.org/home/files/discconsumer_control_in_independent_living_manualedited.pdf. Accessed April 8, 2016.

85. Wilkinson R, Marmot M. Social Determinants of Health: The Solid Facts. Copenhagen: World Health Organization Regional Office for Europe; 2003.
86. Scelza WM, Kirshblum SC, Wuermser LA, et al. Spinal cord injury medicine. Community reintegration after spinal cord injury. Arch Phys Med Rehabil. 2007;88(3 Suppl 1):S71-S75.

87. National Council on Independent Living. How Centers for Independent Living (CILs) Can Assist VR\&E and Veterans. 2012. Available from: www.ncil.org/wp-content/uploads/2013/07/CILs-and-VRE.pdf. Accessed April 8, 2016.

88. US Department of Veterans Affairs (VA). Blueprint for excellence; 2014: p28. Available from: http://www.va.gov/health/docs/VHA_Blueprint_for_Excellence.pdf. Accessed July 26, 2016.
Journal of Multidisciplinary Healthcare

\section{Publish your work in this journal}

The Journal of Multidisciplinary Healthcare is an international, peerreviewed open-access journal that aims to represent and publish research in healthcare areas delivered by practitioners of different disciplines. This includes studies and reviews conducted by multidisciplinary teams as well as research which evaluates the results or conduct of such teams or health

\section{Dovepress}

care processes in general. The journal covers a very wide range of areas and welcomes submissions from practitioners at all levels, from all over the world. The manuscript management system is completely online and includes a very quick and fair peer-review system. Visit http://www.dovepress.com/ testimonials.php to read real quotes from published authors.

Submit your manuscript here: https://www.dovepress.com/journal-of-multidisciplinary-healthcare-journal 